\title{
Supplementary description of Rhithrogena wolosatkae Klonowska (Ephemeroptera, Heptageniidae, hybrida group) from the type locality in the Bieszczady Mountains, Southern Poland.
}

\author{
M. Klonowskal
}

Keywords : Ephemeroptera, Heptageniidae, Rhithrogena, hybrida-group, supplementary description, Poland.

The winged stages of Rhithrogena wolosatkae Klonowsk (male and female imagines and subimagines) and eggs from the type locality in the Bieszczady Mountains, Southern Poland are described and illustrated. Its phyletic relationships and biology are discussed.

Description complémentaire de Rhithrogena wolosatkae Klonowska (Ephemeroptera, Heptageniidae, groupe hybrida) de la localité typique (Bieszczady, sud-est de la Pologne).

Mots clés : Ephemeroptera, Heptageniidae, Rhithrogena, groupe hybrida, description complémentaire, Pologne.

Les stades ailés de Rhithrogena wolosatkae Klonowska (imagos et subimagos mâles et femelles) et les œufs sont décrits et illustrés à partir du matériel provenant de la localité typique (Bieszczady, sud-est de la Pologne). La biologie de cette espèce ainsi que ses affinités phylétiques sont également discutées.

\section{Introduction}

During investigations on mayflies in streams in the Bieszczady Mts in 1985, a new species, Rhithrogena wolosatkae, belonging to the hybrida group, was found (Klonowska 1987). This species was described on the basis of mature and young nymphs and eggs from a mature female nymph. The larvae of the new species are most like those of Rhithrogena hybrida Etn., a species whose correct identification became possible owing to recent complementary description (Sowa 1984, Metzler et al. 1985 b, Sowa et al. 1985, Sowa \& Degrange 1987). Recently, several new species of the hybrida group were also described and the descriptions of some known species were brought to completion (Sowa \& Belfiore 1983, Sartori \& Thomas 1984, Metzler et al. 1985 a, 1985 b ; Sowa et al. 1986, Sowa \& Soldán 1986,

1. Department of Hydrobiology, Institute of Environmental Biology Jagiellonian University, Oleandry 2a, 30-063 Krakow, Poland.
Sowa \& Degrange 1987), with a precise description of the genitalia of the adult males and the structure of the chorion of the egg. This permits correct identification of similar species belonging to this group. In 1987, at the type locality in the Bieszczady Mts, the winged stages of $R$. wolosatkae were also found ; the male imagines were caught during swarming and mating, while female imagines were raised in the laboratory from subimagines captured during the emergence period.

The present paper gives the description of adult specimens of $R$. wolosatkae and redescribes the eggs (from the female imagine since the mature larvae from which eggs were taken for the first description, were preserved in formalin, much less efficient with regard to the delicate structure of the chorion of the egg). The descriptive terminology used by Koss \& Edmunds (1974) is followed in the description of the eggs.

All the material was preserved in $75 \%$ alcohol. 
Rhithrogena wolosatkae Klonowska, 1987

MALE IMAGINE

Body length $10.5-12.0 \mathrm{~mm}$ : forewings 12.0-13.0 mm ; cerci $20-30 \mathrm{~mm}$. Head dark brown, antennae brown. Compound eyes grey in upper part, two dark bands on sides with a pale one in between them. Thorax : pro-, meso-, and metanotum browngrey. Wings slightly brown in the basal part to about $1 / 3$ of the wing length. Longitudinal and cross veins dark brown ; subcosta light brown. Costal area light brown, cross veins dark and distinct also in the proximal part of the area. Large tranverse vein pale. Pterostigma whitish. Fore legs dark brown, mid- and hind ones light brown. In the central part of anterior surface of all legs a greyish-brown, diffuse spot, less distinct on the femora of the middle and hind legs. Abdomen dull brown, dorsal side darker than ventral ; sternites with two oblique dark lines and two small, faint dark spots. Junctions of abdominal segments pale. Nerve ganglia whitish, not readily discernible. Cerci brown, darker in the basal part.

\section{Genitalia}

Styliger dark brown, paler in the middle. Posterior margin distinctly darker, slightly and broadly incurved, lateral projections indistinct. Forceps dark brown, paler at tips (fig. 1). Penial lobes arched outwards. In ventral view, medial part of penis covered by a membraneous part, which slightly overlaps the penial lobes and almost completely covers the titillators (fig. 2). In caudal view, apical part of penial lobe roughly rectangular in outline (fig. 3 ). In lateral view, dorso-apical margin of lobe distinctly projected. Upper margin of external tooth and apex of the lobe form a slightly obtuse angle (fig. 4). Titillators as in fig. 5 .

\section{FEMALE IMAGINE}

Body length $11.0-12.0 \mathrm{~mm}$; forewings 12.5-14.0 mm ; cerci 14.0-20.0 mm. Body brown, paler than in the male imago. Thorax : pronotum and metanotum olivaceous, metanotum brown. Wings pale brown in the basal part to about $1 / 3$ of the wing length. Longitudinal and cross veins brown. Middle and hind legs yellowish-brown, fore legs darker. On the femora dark diffuse spots like in the male imagine (sometimes less distinct). Abdomen light brown (dorsal side darker than ventral) posterior part olive-brown; junctions of segments pale. Terga with a light transverse band and two pale side patches. Nerve gan glia as in the male imago. Cerci light brown, darker at their base. The ventral view of the terminal part of the abdomen with a subgenital plate, as in fig. 6 .

\section{MaLe subiMagine}

Body length $10.0 \mathrm{~mm}$; forewings $12.5 \mathrm{~mm}$; cerci $11.0 \mathrm{~mm}$. General body colouring olivaceous. Junctions of the abdominal segments pale. Terga with two small pale stripes and two small pale spots. Forewings uniformly dark grey, hind ones grey and paler in the upper part ; venation in the colour of the membrane wings. Legs pale yellow, on the femora a diffuse spot as in the male imago, but less distinct. Cerci light brown.

\section{FEMALE SUBIMAGiNE}

Body length $10.0-11.0 \mathrm{~mm}$; forewings $11.0-12.5 \mathrm{~mm}$; cerci $12.0-13.0 \mathrm{~mm}$. Body light brown. Abdominal terga as in the male subimago ; on the sternites only two oblique dark bands visible. Wings, legs, and cerci as in the male subimago.

\section{EGG (FROM FEMALE IMAGINE)}

Egg oval; length $180-200 \mu \mathrm{m}$; width $120-135 \mu \mathrm{m}$ (fig. 7). On one pole a small aggregation of large attachment structure - knobterminated coiled threads (KCT) and very small microgranules (tubercles ; T) (fig. 8). On the other pole only a few large coiled threads and infrequent microgranules (fig. 9). Surface of the chorion rough. On the egg surface, single large coiled threads (smaller than those on the poles), more numerous small coiled threads (SKCT), and infrequent microgranules are visible (fig. 11). Two or, less frequently, three micropyles in the equatorial area of the egg ; the micropylar rim almost glabrous (fig. 10 ).

\section{Material examined}

9 male imagines, 1 male subimagine, 5 female imagines, 3 female subimagines, 7 subimaginal skins; Southern Poland, Bieszczady Mountains, Terebowiec Stream, 920-1100 m alt., 6-10 June 1987. Leg. M. Klonowska.

\section{AFFINITES}

The species $R$. wolosatkae is very close to $R$. hybrida Etn. (Sowa 1984 ; Sowa ct al. 1985). The distinguishing features for larvae were given in the 

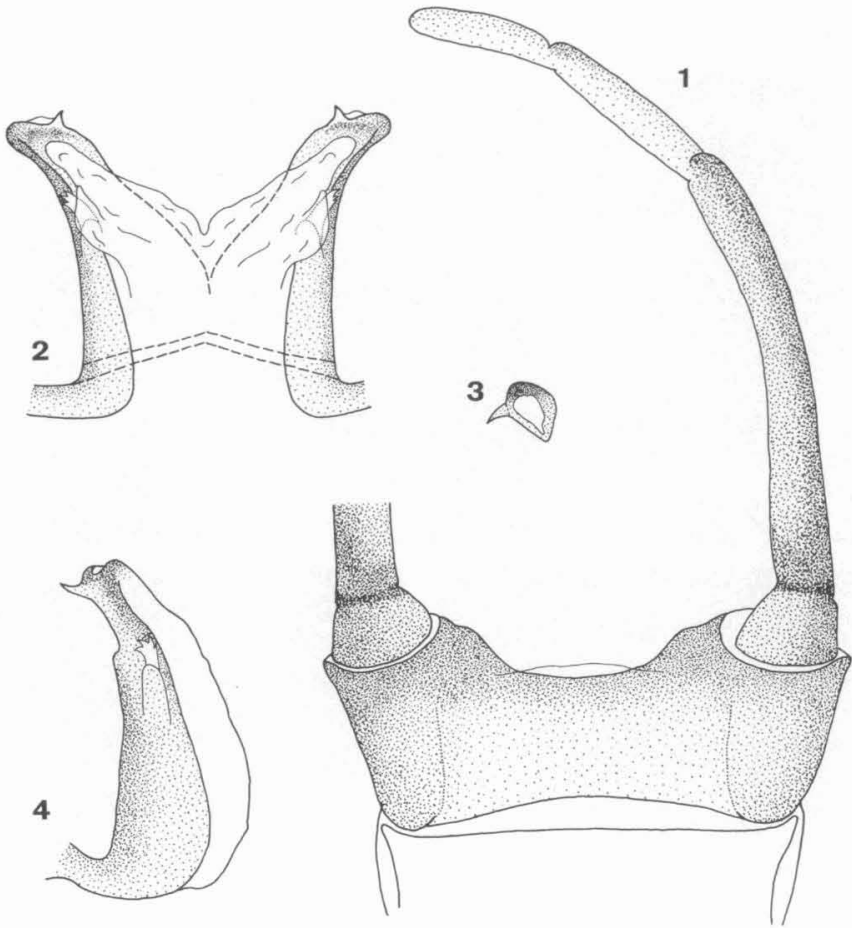

5
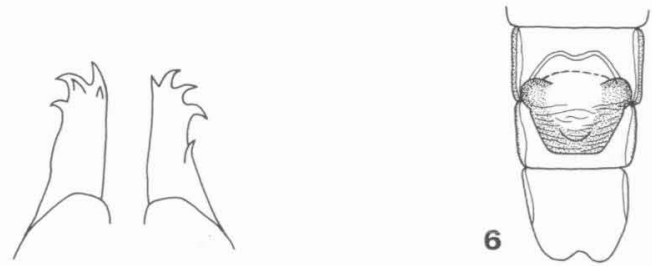

Fig. 1-6. Rhithrogena wolosatkae : male imagine (fig. 1-5) ; female imagine (fig. 6).

1 : styliger and fragment of forceps in ventral view $; 2:$ penis in ventral view ; 3 : apical part of penial lobe in ventral view ; 4 : penis in lateral view ; $5:$ titillators ; $6:$ posterior part of abdomen in ventral view. 

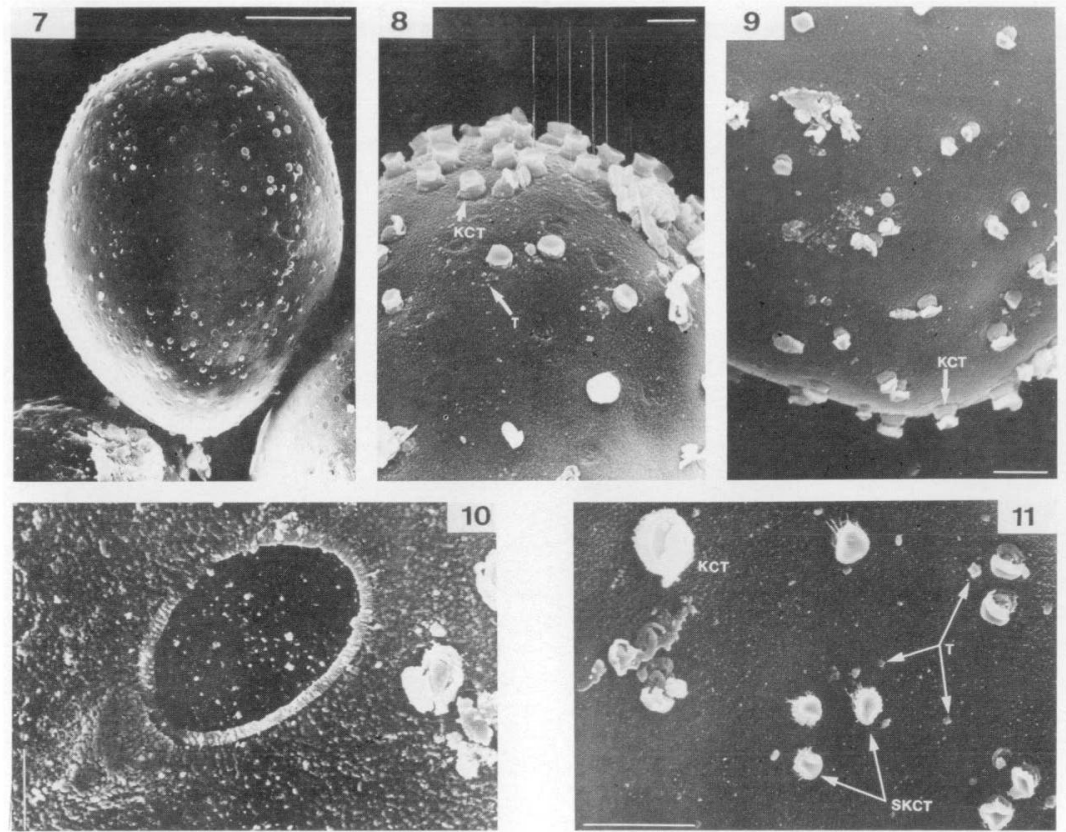

Fig. 7-11. Rhithrogena wolosatkae, egg (critical point dried, gold coated, JSM-35 JEOL. $25 \mathrm{kV}$ ).

7 : general view of egg (scale $50 \mu \mathrm{m}$ ) ; 8: polar part more enlarged (scale $10 \mu \mathrm{m}$ ) ; 9 : polar part less enlarged (scale $10 \mu \mathrm{m}$ ) ; 10 : micropyle (scale $5 \mu \mathrm{m}$ ) ; 11 : chorion surface : large knob-terminated coiled threads (KCT), small knob-terminated coiled threads (SKCT), microgranules (tubercles; T) (scale $10 \mu \mathrm{m}$ ).

original description (Klonowska 1987). The imago and the subimago of $R$. wolosatkae, like the larvae, have diffuse darker spot on the femora, which are absent in $R$. hybrida. The new species also differs from $R$. hybrida in the body colour, the wings coloration and the genitalia, in particular the posterior margin of the styliger and the penis in caudal, ventral (large membraneous part) and lateral (distinct projection) views.
The subgenital plate of female in somewhat different from that in $R$. hybrida. The egg of $R$. wolosatkae is different than in $R$. hybrida by the absence of large aggregation of knob-terminated coiled threads and numerous microgranules on both poles of egg. The surface of the egg chorion of $R$. wolosatkae is also different than in $R$. hybrida where only numerous large coiled threads are visible : in $R$. wolosatkae infrequent large coiled threads occur, 
more numerous small coiled threads and single microgranules. The micropylar rim of $R$. wolosatkae is somewhat wider than in $R$. hybrida.

\section{DISTRIBUTION AND BIOLOGY}

$R$. wolosatkae has been found only in Poland in two streams : the Wolosatka and Terebowiec in the Bieszczady Mts (Southern Poland) at $800-1100 \mathrm{~m}$ alt. The habitat of this species consists of large and medium stones on coarse gravel in the midstream (current velocity $1.5-2.5 \mathrm{~m} / \mathrm{s}$ ). Here it is the only representative of the hybrida group. $R$. wolosatkae belongs to a group of univoltine winter species (Clifford 1982, Sowa 1975). The imagine are present in spring (end of May - beginning of June). Young, identifiable larvae appear in the streams in autumn (Klonowska 1987), thus the eggs do not go through a phase of summer dormancy. Emergence takes place on sunny days around midday, directly from the midstream (the larva approaches the water surface where the subimagine metamorphorses on, and then flies towards the nearest trees or bushes). Mating and swarming take place at dusk, some distance away the water, in the open (clearings, places not overgrown by trees) ; the male imagines form fairly small swarms at about $10-15 \mathrm{~m}$ height. The life cycle of $R$. wolosatkae is close to that of $R$. hybrida (Sowa \& Degrange 1987). $R$. wolosatkae, however, emerges earlier and its flight period is shorter.

$R$. wolosatkae was only found in two streams in the Bieszczady Mts, but never in other similar streams of the Polish Carpathians, and it is not likely to be found in the Alps. Hence it may be considered as an east Carpatian species.

\section{Acknowledgement}

I am greatly indebted to the late Prof. Ryszard Sowa for his interest, advice, and constructive comments during the preparation of this paper, and for his critical review of the manuscript.
References

Cliffort (H.F.). 1982. - Life cycles of mayflies (Ephemeroptera), with special reference to volinism. Quaest. Ent., 18 (1-4) : 15-90.

Klonowska (M.). 1987. - Rhithrogena wolosatkae n. sp., a new species of the hybrida-group from Southern Poland (Ephemeroptera, Heptageniidae). Pol, Pismo Entomol., 57 : 251-256.

Koss (R.W.) \& Edmunds (G.F.). 1974. - Ephemeroptera eggs and their contribution to the phylogenetic studies of the order. Zoot. J. Linn. Soc., $55: 267-349$.

Metzler (M.), Tomka (I.) \& Zurwerra (A.). 1985 a. - Erstbeschreibung der Larve und Subimago von Rhithrogena puthzi Sowa, 1984, sowie Diskussion der morphologischen Merkmale von $R$. puthzi und $R$. endenensis Metzler, Tomka \& Zurwerra, 1985 (Ephemeroptera). Entomol, Ber. Luzern, 13 : $105-106$

Metzler (M.), Tomka (I.) \& Zurwerra (A.). 1985 b. - Beitrag zur Kenntnis der europäischen Rhithrogena-Arten : nivata, hybrida und hercynia, sowie Beschreibung von zwei neve Arten. Folia Entomol. Hung., 46 (2) : 117-135.

Sartori (M.) \& Thomas (A.G.B.). 1984. - Identité et redécotiverte de Rhithrogena nivata (Eaton, 1871) (Ephemeroptera, Heptageniidae). Ann/s. Limnol., 20 (3) : 203-208.

Sowa (R.). 1975. - Ecology and biogeography of mayflies (Ephemeroptera) of running waters in the Polish part of the Carpathians, 2. Life Cycles. - Acta Hydrobiol., 17 (4) : 319-353.

Sowa (R.). 1984. - Contribution à la connaissance des especes européennes de Rhithrogena Eaton (Ephemeroptera, Heptageniidae) avec le rapport particulier aux espèces des Alpes et des Carpates, - Proc. IVth Intern. Confer. Ephemeroptera. V. Landa et al. (eds.), CSAV, Bechyne: 37-52.

Sowa (R.) \& Belfiore (C.). 1983. - Rhithrogena reatina sp. n., a new species of the hybrida group from Central italy (Ephemeroptera, Heptageniidae). Boll. Ass. Romana Entomol., $38: 5-8$.

Sowa (R.) \& Degrange (Ch.), 1987, - Rhithrogena du groupe hybrida (Ephemeroptera, Heptageniidae) des Alpes françaises. - Acia Hydrobiol., 29 (1) : 71-87.

Sowa (R.), Degrange (Ch.) \& Sartori (M.). 1986. - Rhithrogena gratianopolitana sp. n. du groupe hybrido (Ephemeroptera, Heptageniidae) des Alpes françaises et helvétiques. Bull. Soc. Vaud. Sc. Nat., 78, $2: 215-223$.

Sowa (R.), Gaino (E.) \& Degrange (Ch.). 1985. - Description de Rhithrogena hybrida Eaton, 1885 (Ephemesoptera, Heptageniidae) à partir d'exemplaires de l'une des stations types (Chalets de Joux-Plane, Haute-Savoie, France). Pol. Pismo Entomol., 55: 135-137.

Sowa (R.) \& Soldán (T.). 1986. - Three new species of the Rhithrogena hybrida group from Poland and Czechoslovakia with a supplementary description of $R$. hercynia Landa, 1969 (Ephemeroptera, Heptageniidae). Pol. Pismo Ensomol. 56 : $557-572$. 